Article

\title{
Coumarins from Angelica lucida L. - Antibacterial Activities
}

\section{Jaroslaw Widelski ${ }^{1}$, Milena Popova ${ }^{2}$, Konstantia Graikou ${ }^{3}$, Kazimierz Glowniak ${ }^{1}$ and Ioanna Chinou $^{3, *}$}

1 Department of Pharmacognosy with Medicinal Plant Laboratory, Skubiszewski Medicinal University of Lublin, 1 Chodzki str., 20-093, Poland; E-mails:yarpen222@interia.pl (J.W.), kglowniak@pharmacognosy.org (K.G.)

2 Institute of Organic Chemistry with Centre of Phytochemistry, Bulgarian Academy of Sciences, Acad. G. Bonchev str., bl.9, 1113 Sofia, Bulgaria; E-mail: popova@orgchm.bas.bg (M.P.)

3 Division of Pharmacognosy and Chemistry of Natural Products, Faculty of Pharmacy, University of Athens, Athens 15771, Greece; E-mail: kgraikou@pharm.uoa.gr (K.G.)

* Author to whom correspondence should be addressed; E-mail: ichinou@pharm.uoa.gr

Received: 1 July 2009; in revised form: 20 July 2009/ Accepted: 20 July 2009 /

Published: 27 July 2009

\begin{abstract}
The first phytochemical investigation of the fruits of Angelica lucida has led to the isolation and characterization of five known coumarins (imperatorin, isoimperatorin, heraclenol, oxypeucedanin hydrate and heraclenin). All isolated compounds were identified by means of spectral and literature data. The extracts and the isolated constituents from A. lucida have been also evaluated for their antimicrobial activity against six Gram positive and negative bacteria, two oral pathogens and three human pathogenic fungi, exhibiting an interesting antimicrobial profile.
\end{abstract}

Keywords: Angelica lucida; apiaceae; coumarins; antibacterial activity

\section{Introduction}

Angelica lucida L. is a species of Angelica genus (Apiaceae) known by the common names seacoast angelica and sea-watch. This plant is generally similar in appearance to other Angelicas with tall, dense umbels of yellowish-white flowers. As its common names suggest, this plant is found most often along the coastline. Its distribution includes the east and west coasts of North America, plus parts of 
East Asia. Tender parts of the plant have been used by the Eskimos as food, analgesic and tonic against common colds. The roots as well as the young stems of the plant have been taken as a preventative medicine [1]. The presence in the genus Angelica of coumarins [2], which are known for a broad spectrum of pharmacological properties [3], is well documented This evidence together with our research interests concerning the chemical composition of different Apiaceae (Umbeliferae) plants, prompted us to study the chemical composition of the title plant. Our study of Angelica lucida fruits has led to the isolation and characterization of five known coumarins. These compounds have been also isolated from other species of the genus Angelica $[4,5,6]$, but for the first time to our knowledge from A. lucida, while terpenes have been previously referred from the essential oil of the seeds [7].

\section{Results and Discussion}

Examination of the petroleum ether and methanolic extracts of A. lucida fruits led to the isolation of five known coumarins: imperatorin (1) [4], isoimperatorin (2) [4], heraclenol (3) [4], oxypeucedanin hydrate (4) [4] and heraclenin (5) [8] (Figure 1). To the best of our knowledge, all determined coumarins, are reported for the first time from the studied plant. Constituents 1-4 have been also isolated from a quite big number of other Angelica species, and could be characterized as a chemotaxonomic tool of the genus, while heraclenin (5) has been previously isolated only from three Angelica taxa: A. ursine [9], A. genuflexa [10] and A. silvestris [11]. The results of our study support the conclusion that coumarins are among the most characteristic and distinguishable chemical markers of the genus, as it has been previously mentioned, as well as of the Apiaceae family $[1,2,12,13]$.

Figure 1. The structures of compounds 1-5.

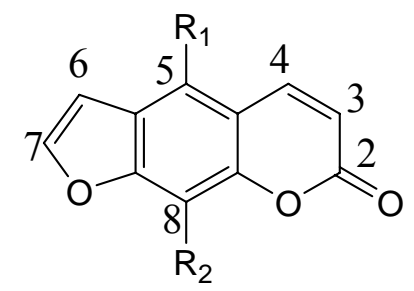

\begin{tabular}{|c|c|c|}
\hline & $\mathbf{R}_{\mathbf{1}}$ & $\mathbf{R}_{2}$ \\
\hline 1 & $\mathrm{H}$ & \\
\hline 2 & & $\mathrm{H}$ \\
\hline 3 & $\mathrm{H}$ & $\mathrm{OH}$ \\
\hline 4 & $\mathrm{OH}$ & $\mathrm{H}$ \\
\hline 5 & $\mathrm{H}$ & \\
\hline
\end{tabular}




\section{Antimicrobial activity}

The tested material was the petroleum ether and methanolic extracts as well as the isolated coumarins. The crude extracts of the plant were moderately active against Gram positive and negative bacteria and oral pathogens, while the tested extracts and isolated compounds were inactive against the three assayed Candida species. All isolated coumarins have been studied, to the best of our knowledge, for the first time against the oral pathogens $S$. mutans and $S$. viridans and generally they inhibited all assayed bacterial strains (MIC between 0.012 and $0.85 \mathrm{mg} / \mathrm{mL}$ ) $[12,13,14]$ while 1 and 2 appeared as the most active (MICs 0.012 and $0.70 \mathrm{mg} / \mathrm{mL}$ ). This is in agreement with the observations of Schinkovitz et al. [12] who found that the presence of an isoprenyl unit attached to the carbocyclic ring favors their antimicrobial activities and Tada et al. [13], who showed a broad spectrum of activities of several similar furanocoumarins and their glucosides. Both Gram positive and negative bacteria displayed the same sensitivity to tested coumarins, while $P$. aeruginosa appeared as the most resistant strain, which as a result is in accordance with previous scientific results from Rosselli et al. [14].

The results of our antibacterial studies could be attributed to the coumarin ring as such natural products are known since the 1950s to exert their effects by inhibition of bacterial nucleic acid synthesis [14]. It has been proved that the addition of a prenyl group to the furanocoumarin skeleton results in an increase in lipophilicity of the molecule, facilitating its passage though the thick bacterial membrane to its target [15].

\section{Experimental}

\section{General}

NMR spectra were recorded in $\mathrm{CDCl}_{3}$ on a Bruker $\mathrm{AC} 200$ at $50 \mathrm{MHz}$ and on a Bruker Avance 400 at $400 \mathrm{MHz}$ and the UV spectra on a Shimadzu UV-160A spectrophotometer.

\section{Plant material}

Angelica lucida L. (Apiaceae) fruits were collected from the Botanical Garden of the Department of Pharmacognosy (Medical University of Lublin, Poland) in September of 2006 (voucher specimen $n$. 2534). Seeds for cultivation were provided by Dr Toshiro Shibata (Research Centre for Medicinal Plant Resources) from Coast line of Hamatonbetsutyo, Esashigun, Hokkaido, Japan (ca $142^{\circ} 22^{\prime} \mathrm{E}$, $\left.45^{\circ} 7^{\prime} \mathrm{N}\right)$ and were also identified botanically by him.

\section{Extraction and isolation}

The air-dried aerial parts of the plant were pulverized and extracted with petroleum ether and methanol. Their petroleum ether and methanolic residues were subjected to chromatographic separations, mainly by column LC (VLC, CC). By these means, five coumarins were isolated: imperatorin $(1,51.0 \mathrm{mg} / 41.3 \mathrm{mg}$ isolated from the petroleum ether extract plus $9.7 \mathrm{mg}$ from the methanolic one), isoimperatorin $(2,31.7 \mathrm{mg})$, heraclenol $(3,9.4 \mathrm{mg})$, oxypeucedanin hydrate 
$(4,21.8 \mathrm{mg})$ and heraclenin $(5,17.7 \mathrm{mg})$. Their structures were established by spectroscopic methods including 1D- and 2D-NMR experiments.

Table 1. Antimicrobial activities $\mathrm{MIC}$ values $(\mathrm{mg} / \mathrm{mL}, \mathrm{n}=3)$ of the assayed extracts and isolated compounds.

\begin{tabular}{|c|c|c|c|c|c|c|c|c|c|c|c|}
\hline & 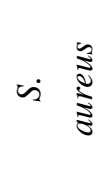 & 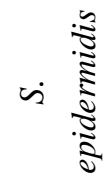 & 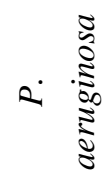 & 떠 $\frac{\tilde{E}}{\tilde{Z}}$ & 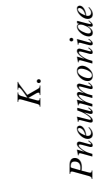 & 4 & vi $\frac{\mathfrak{E}}{\Xi}$ & vi $\frac{\mathscr{2}}{\tilde{z}}$ & 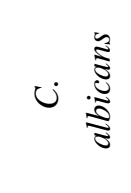 & 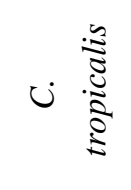 & ن $\frac{\frac{5}{0}}{\frac{5}{a}}$ \\
\hline $\begin{array}{l}\text { petroleum ether } \\
\text { extract }\end{array}$ & $\begin{array}{l}3.40 \\
\pm 0.4\end{array}$ & $\begin{array}{l}3.80 \\
\pm 0.5\end{array}$ & $\begin{array}{l}3.75 \\
\pm 0.4\end{array}$ & $\begin{array}{l}3.64 \\
\pm 0.6\end{array}$ & $\begin{array}{l}4.10 \\
\pm 0.7\end{array}$ & $\begin{array}{l}2.97 \\
\pm 0.3\end{array}$ & $\begin{array}{l}2.68 \\
\pm 0.3\end{array}$ & $\begin{array}{l}2.35 \\
\pm 0.4\end{array}$ & inactive & inactive & inactive \\
\hline $\begin{array}{c}\text { methanolic } \\
\text { extract }\end{array}$ & $\begin{array}{r}1.97 \\
\pm 0.3\end{array}$ & $\begin{array}{r}1.85 \\
\pm 0.2\end{array}$ & $\begin{array}{l}2.28 \\
\pm 0.3\end{array}$ & $\begin{array}{l}2.90 \\
\pm 0.4\end{array}$ & $\begin{array}{l}2.76 \\
\pm 0.2\end{array}$ & $\begin{array}{l}2.39 \\
\pm 0.3\end{array}$ & $\begin{array}{l}2.20 \\
\pm 0.2\end{array}$ & $\begin{array}{l}2.47 \\
\pm 0.2\end{array}$ & inactive & inactive & inactive \\
\hline imperatorin & $\begin{array}{l}0.045 \\
\pm 0.1\end{array}$ & $\begin{array}{l}0.035 \\
\pm 0.2\end{array}$ & $\begin{array}{c}0.070 \\
\pm 0.1\end{array}$ & $\begin{array}{l}0.028 \\
\pm 0.2\end{array}$ & $\begin{array}{l}0.030 \\
\pm 0.3\end{array}$ & $\begin{array}{l}0.025 \\
\pm 0.2\end{array}$ & $\begin{array}{l}0.018 \\
\pm 0.2\end{array}$ & $\begin{array}{l}0.015 \\
\pm 0.1\end{array}$ & inactive & inactive & inactive \\
\hline isoimperatorin & $\begin{array}{l}0.040 \\
\pm 0.2\end{array}$ & $\begin{array}{l}0.032 \\
\pm 0.1\end{array}$ & $\begin{array}{l}0.070 \\
\pm 0.3\end{array}$ & $\begin{array}{l}0.025 \\
\pm 0.2\end{array}$ & $\begin{array}{l}0.030 \\
\pm 0.2\end{array}$ & $\begin{array}{l}0.023 \\
\pm 0.1\end{array}$ & $\begin{array}{l}0.015 \\
\pm 0.1\end{array}$ & $\begin{array}{l}0.012 \\
\pm 0.2\end{array}$ & inactive & inactive & inactive \\
\hline heraclenol & $\begin{array}{l}0.68 \\
\pm 0.3\end{array}$ & $\begin{array}{l}0.64 \\
\pm 0.2\end{array}$ & $\begin{array}{l}0.70 \\
\pm 0.2\end{array}$ & $\begin{array}{l}0.77 \\
\pm 0.1\end{array}$ & $\begin{array}{l}0.85 \\
\pm 0.4\end{array}$ & $\begin{array}{l}0.67 \\
\pm 0.3\end{array}$ & $\begin{array}{l}0.53 \\
\pm 0.2\end{array}$ & $\begin{array}{l}0.50 \\
\pm 0.2\end{array}$ & inactive & inactive & inactive \\
\hline $\begin{array}{l}\text { oxypeucedanin } \\
\text { hydrate }\end{array}$ & $\begin{array}{l}0.65 \\
\pm 0.3\end{array}$ & $\begin{array}{l}0.60 \\
\pm 0.2\end{array}$ & $\begin{array}{l}0.81 \\
\pm 0.3\end{array}$ & $\begin{array}{l}0.80 \\
\pm 0.4\end{array}$ & $\begin{array}{l}0.72 \\
\pm 0.3\end{array}$ & $\begin{array}{l}0.65 \\
\pm 0.2\end{array}$ & $\begin{array}{l}0.57 \\
\pm 0.2\end{array}$ & $\begin{array}{l}0.55 \\
\pm 0.2\end{array}$ & inactive & inactive & inactive \\
\hline heraclenin & $\begin{array}{l}0.80 \\
\pm 0.2\end{array}$ & $\begin{array}{l}0.82 \\
\pm 0.1\end{array}$ & $\begin{array}{l}0.85 \\
\pm 0.4\end{array}$ & $\begin{array}{l}0.85 \\
\pm 0.6\end{array}$ & $\begin{array}{l}0.77 \\
\pm 0.2\end{array}$ & $\begin{array}{l}0.70 \\
\pm 0.5\end{array}$ & $\begin{array}{l}0.75 \\
\pm 0.2\end{array}$ & $\begin{array}{l}0.83 \\
\pm 0.4\end{array}$ & inactive & inactive & inactive \\
\hline netilmicin & $\begin{array}{l}0.004 \\
\pm 0.1\end{array}$ & $\begin{array}{l}0.004 \\
\pm 0.1\end{array}$ & $\begin{array}{l}0.088 \\
\pm 0.3\end{array}$ & $\begin{array}{l}0.008 \\
\pm 0.2\end{array}$ & $\begin{array}{l}0.008 \\
\pm 0.2\end{array}$ & $\begin{array}{l}0.010 \\
\pm 0.1\end{array}$ & $\mathrm{nt}$ & $\mathrm{nt}$ & $\mathrm{nt}$ & $\mathrm{nt}$ & $\mathrm{nt}$ \\
\hline $\begin{array}{l}\text { amoxicillin with } \\
\text { clavulanic acid }\end{array}$ & $\begin{array}{l}0.003 \\
\pm 0.2\end{array}$ & $\begin{array}{l}0.003 \\
\pm 0.1\end{array}$ & $\begin{array}{l}0.003 \\
\pm 0.2\end{array}$ & $\begin{array}{l}0.042 \\
\pm 0.2\end{array}$ & $\begin{array}{l}0.048 \\
\pm 0.3\end{array}$ & $\begin{array}{l}0.005 \\
\pm 0.1\end{array}$ & $\mathrm{nt}$ & $\mathrm{nt}$ & $\mathrm{nt}$ & $\mathrm{nt}$ & nt \\
\hline 5-flucytocine & $\mathrm{nt}$ & $\mathrm{nt}$ & $\mathrm{nt}$ & nt & nt & $\mathrm{nt}$ & $\mathrm{nt}$ & $\mathrm{nt}$ & $\begin{array}{c}0.1 \times 10^{-3} \\
\quad \pm 0.1\end{array}$ & $\begin{array}{c}1 \times 10^{-3} \\
\pm 0.2\end{array}$ & $\begin{array}{c}10 \times 10^{-3} \\
\pm 0.1\end{array}$ \\
\hline amphotericin B & $\mathrm{nt}$ & $\mathrm{nt}$ & $\mathrm{nt}$ & nt & $\mathrm{nt}$ & $\mathrm{nt}$ & nt & $\mathrm{nt}$ & $\begin{array}{l}1 \times 10^{-3} \\
\pm 0.3\end{array}$ & $\begin{array}{c}0.5 \times 10^{-3} \\
\pm 0.1\end{array}$ & $\begin{array}{c}0.4 \times 10^{-3} \\
\pm 0.1\end{array}$ \\
\hline sanguinarine & $\mathrm{nt}$ & $\mathrm{nt}$ & nt & $\mathrm{nt}$ & $\mathrm{nt}$ & $\mathrm{nt}$ & $\begin{array}{l}0.015 \\
\pm 0.1\end{array}$ & $\begin{array}{l}0.015 \\
\pm 0.2\end{array}$ & $\mathrm{nt}$ & nt & $\mathrm{nt}$ \\
\hline
\end{tabular}

nt: not tested.

\section{Antimicrobial activity assays}

Antimicrobial activity against bacteria, oral pathogens and fungi was determined using the agar dilution technique [16]. For all assays, stock solutions of the tested extract and pure compounds in sterile 
distilled water with $10 \%$ Tween 80 have been prepared at 10 and $1 \mathrm{mg} / \mathrm{mL}$, respectively. Serial dilutions of the stock solutions in broth medium $(100 \mu \mathrm{L}$ of Müller-Hinton broth, Sabouraud broth for fungi and blood agar $10 \%$ for oral pathogens) were prepared in a microtiter plate (96 wells). Then $1 \mu \mathrm{L}$ of the microbial suspension (the inoculum, in sterile distilled water) was added to each well. For each strain, the growth conditions and the sterility of the medium were checked and the plates were incubated at $37^{\circ} \mathrm{C}$ and the MICs were determined as the lowest concentrations preventing visible growth.

\section{Microorganisms}

A panel of microorganisms, including two Gram positive bacteria: Staphylococcus aureus (ATCC 25923) and S. epidermidis (ATCC 12228); four Gram negative bacteria: Escherichia coli (ATCC 25922), Enterobacter cloacae (ATCC 13047), Klebsiella pneumoniae (ATCC 13883) and Pseudomonas aeruginosa (ATCC 227853); three pathogenic fungi: Candida albicans (ATCC 10231), C. tropicalis (ATCC 13801) and C. glabrata (ATCC 28838) and the oral pathogens Streptococcus mutans and S. viridans, were used. Standard antibiotics (netilmicin and amoxicillin with clavulanic acid) were used in order to control the sensitivity of the tested bacteria and 5-flucytocine, amphotericin $\mathrm{B}$ and sanguinarine were used in order to control the tested fungi and the oral pathogens [16].

\section{Statistical analysis}

Variance analysis of the results was taken using averages_SD. Each value is the mean of three replications.

\section{Acknowledgements}

The authors would like to thank Dr Toshiro Shibata, Director of Hokkaido Laboratory Research Centre for Medicinal Plant Resources, National Institute of Biomedical Innovation (NiBiO) Hokkaido, Japan, for providing the seeds of the cultivated plant material, as well as for their botanical identification.

\section{References}

1. French, D.H. The Biology \& Chemistry of the Umbelliferae; Heywood, V.H., Ed.; Linn. Soc., Academic Press: London, UK, 1971; pp. 385-412.

2. Murray, R.D.H. Progress in the Biochemistry of Organic Natural Products; Springer: New York, NY, USA, 1978; Vol. 35.

3. Hoult, J.R.S.; Payá, M. Pharmacological and biochemical actions of simple coumarins: Natural products with therapeutic potential. Gen. Pharmacol. 1996, 27, 713-722.

4. Harkar, S.; Razdan, T.K.; Waight, E.S. Steroids, chromone and coumarins from Angelica officinalis. Phytochemistry 1984, 23, 419-426.

5. Kwon, Y.S.; Kobayashi, A.; Kajiyama, S.I.; Kawazu, T.K.; Kanzaki H.; Kim C.M. Antimicrobial constituents of Angelica dahurica roots. Phytochemistry 1997, 44, 887-889.

6. Thastrup, O.; Lemmich, J. Furocoumarin glucosides of Angelica archangelica subspecies litoralis. Phytochemistry 1983, 22, 2035-2037. 
7. Lawrence, B.M.; Morton, J.K. Acorenone-B in Angelica lucida oil. Phytochemistry 1974, 13, 528.

8. Miftakhova, A.F.; Burasheva, G.S.; Abilov, Z.A.; Ahmad, V.U.; Zahid, M. Coumarins from the aerial part of Halocnemum strobilaceum. Fitoterapia 2001, 72, 319-321.

9. Nikonov, G.K.; Pimenov, M.G. Lactones from Angelica ursine fruits. Khim. Prir. Soedin. 1969, 5, 318-319.

10. An, R.B.; Park, B.Y.; Kim, J.H.; Kwon, O.K.; Lee, J.; Min, B.S.; Ahn, K.S.; Oh, S.R.; Lee, H.K. Coumarins and chromones from Angelica genuflexa. Nat. Prod. Sci. 2005, 11, 79-84.

11. Milosavljevic, S.; Jeremic, D.; Nevescanin, M.; Radovanovic, G.; Zivanovic, P.; Todorovic, B.; Slavkovska, V.; Vajs, V. Furo- and pyranocoumarins from plant species Angelica silvestris and Peucedanum austriacum. J. Serbian Chem. Soc. 1993, 58, 997-1001.

12. Schinkovitz, A.; Gibbons, S.; Stavri, M.; Cocksedge, M.J.; Bucar, F. Ostruthin: An antimycobacterial coumarin from the roots of Peucedanum ostruthium. Planta Med. 2003, 69, 369-371.

13. Tada, Y.; Shikishima, Y.; Takaishi, Y.; Shibata, H.; Higuti, T.; Honda, G.; Ito, M.; Takeda, Y.; Kodzhimatov, O.; Ashurmetov, O; Ohmoto, Y. Coumarins and $\gamma$-pyrone derivatives form Prangos pabularia antibacterial activity and inhibition of cytokine release. Phytochemistry 2002, 59, 649-654.

14. Rosselli, S.; Maggio, A.; Bellone, G.; Formisano, C.; Basile, A.; Cicala, C.; Alfieri, A.; Mascolo, N.; Bruno, M. Antibacterial and Anticoagulant Activities of Coumarins Isolated from the Flowers of Magydaris tomentosa. Planta Med. 2007, 72, 116-120.

15. Stavri, M.; Gibbons, S. The antimycobacterial constituents of dill (Anethum graveolens). Phytother. Res. 2005, 19, 938-941.

16. Passi, S.; Aligiannis, N.; Pratsinis, H.; Skaltsounis, A.L.; Chinou, I.B. Biologically active Triterpenoids of Cephalaria ambrosioides roots. Planta Med. 2009, 75, 163-167.

Sample Availability: Samples of the compounds are available from the authors.

(C) 2009 by the authors; licensee Molecular Diversity Preservation International, Basel, Switzerland. This article is an open-access article distributed under the terms and conditions of the Creative Commons Attribution license (http://creativecommons.org/licenses/by/3.0/). 